\title{
Effect of Wind Speed on Reaction Coefficient of Different Building Height
}

\author{
Chunli Ren ${ }^{1,}$ a , Yun Liü,b \\ ${ }^{1}$ No.9 Daxuexidao. Tangshan City, Hebei Province, China \\ ${ }^{2}$ No.30 Beisanhuandonglu. Beijing, China \\ arcl9169@163.com, bliuyun@cabrtech.com
}

Keywords: height of building; convection heat transfer coefficient; reaction coefficient.

Abstract. The air-conditioning load will increase in the rooms with the same envelope size and same thermal performance, but in different height. Thermal reaction coefficient method is widely used in calculation of air-conditioning load. Change rule of thermal reaction coefficient can be confirmed by a calculation case in this paper. With the increase of the height of building, the reaction coefficient will increase.

\section{Introduction}

Heat transfer on the building surface is greatly affected by corresponding wind speed. Especially in the high-rise building, building surface wind speed will increase with height, so that the surface heat transfer enhancement. Meanwhile additional heat loss is accompanied by increased air-conditioning load.

With the change rule of reaction coefficient, the air-conditioning load and corresponding capacity of air-conditioning system can be calculated accurately. The rule also can be used to analyze internal force and deformation in concrete structure building to reduce the risk of surface cracking produced by solar radiation and convection heat transfer.

\section{Wind Speed Distribution Law}

At low altitude, the wind speed near to the ground surface will increase with height increasing due to surface friction. Below $100 \mathrm{~m}$, the average wind speed profile is fitted by the logarithmic equation. In $100 \mathrm{~m}-300 \mathrm{~m}$ height, the average wind speed profile is fitted by exponential law. And the height above ground 300m-500m, wind speed achieves maximum, because air flowing almost not be affected by ground surface friction but action of air pressure. Conclusion above also can be revealed in equation (1), (2). Wind speed variation presets logarithmic law in $10 \mathrm{~m}-100 \mathrm{~m}$ height, and presets index law in 100m-300m height.

Wind speed distribution in logarithmic law (10m-100m) is shown in equation (1):

$$
\frac{\overline{\mathrm{u}}}{\overline{\mathrm{u}}_{1}}=\frac{\ln \mathrm{z}-\ln \mathrm{z}_{0}}{\ln \mathrm{z}_{1}-\mathrm{z}_{0}}[1]
$$

Wind speed distribution in index law $(100 \mathrm{~m}-300 \mathrm{~m})$ is shown in equation2:

$$
\overline{\mathrm{u}}=\overline{\mathrm{u}}_{1}\left(\frac{\mathrm{Z}}{\mathrm{Z}_{1}}\right)^{\alpha}
$$

Where $Z_{0}$ is roughness height(In the neutral layer, roughness height is the height which vertical wind speed is approaching to zero, roughness height is $1.1 \mathrm{~m}$ in Beijing), $Z_{1}$ is standard 
height(Standard height is $10 \mathrm{~m}$ in most nations), $\overline{\mathrm{u}}$ is average speed in $\mathrm{Z}$ height, $\overline{\mathrm{u}}_{1}$ is average speed in $10 \mathrm{~m}$ height, $\alpha$ is wind speed profile index.

\section{Convective Heat Transfer Coefficient in Different Height and Correspondent Wind Speed}

Typically, convective heat transfer coefficient can be calculated and tested in natural convection state. But in fact, the wind speed on high-rise building surface increases with height. In the case of considering wind direction parallel to wall surface, the equation (3) is used to calculate convection heat transfer coefficient.

$$
\alpha=5.7+3.8 \mathrm{v}[2]
$$

Where $\alpha$ is the heat transfer coefficient, $\mathrm{v}[\mathrm{m} / \mathrm{s}]$ is the velocity on wall surface.

According to equation (3), convective heat transfer coefficient in different height and correspondent wind speed in $10 \mathrm{~m}, 100 \mathrm{~m}, 200 \mathrm{~m}$ and $300 \mathrm{~m}$ height can be calculated in Table1.

Table1. convective heat transfer coefficient and correspondent wind speed in different height

\begin{tabular}{|c|c|c|c|c|}
\hline $\mathrm{Z}[\mathrm{m}]$ & 10 & 100 & 200 & 300 \\
\hline Wind Speed $[\mathrm{m} / \mathrm{s}]$ & 4.5 & 9.19 & 12.1 & 13.9 \\
\hline$\alpha\left[\mathrm{W} / \mathrm{m}^{2} \cdot{ }^{\circ} \mathrm{C}\right]$ & 22.8 & 40.622 & 51.68 & 58.52 \\
\hline
\end{tabular}

\section{Reaction Coefficient Method}

The reaction coefficient method proposed by D. G. Stephenson and G. P. Mitalas in Canada in the late 60 's. In essence, reaction coefficient method integrates modern control theory into the Laplace transform and the invert transform. In the premise of considering the wall as a thermal system, the heat flux variation caused by the disturbance of triangle temperature wave cell is obtained by decomposing the boundary condition which varies continuously into a series of triangular pulses by multiplying the pulse height with the triangle pulse cell. In the view that each pulse is linearly independent and thermal system is linear system, the whole heat process can be obtained by application of superposition principle and convolution principle.

\section{The Transfer Matrix[3]}

From the theory of heat transfer, the thermal field and heat flux variation trend can be obtained by solving the following partial differential equations which is shown in equation (4):

$$
\begin{cases}\frac{\partial(\mathrm{x}, \tau)}{\partial \tau}=\mathrm{a} \frac{\partial \mathrm{t}^{2}(\mathrm{x}, \tau)}{\partial \mathrm{x}^{2}} & (0<\mathrm{x}<1, \tau>0) \\ \mathrm{q}(\mathrm{x}, \tau)=-\lambda \frac{\partial \mathrm{t}(\mathrm{x}, \tau)}{\partial \mathrm{x}} & (0<\mathrm{x}<1, \tau>0) \\ \mathrm{t}(\mathrm{x}, 0)=0 & \end{cases}
$$

(4)

The equation (4) for Laplace transform is shown in equation (5):

$$
\left\{\begin{array}{l}
\mathrm{T}(\mathrm{x}, \mathrm{s})=\operatorname{ch}\left(\sqrt{\frac{\mathrm{s}}{\mathrm{a}} \mathrm{x}}\right) \mathrm{T}(0, \mathrm{~s})-\operatorname{sh}\left(\sqrt{\frac{\mathrm{s}}{\mathrm{a}} \mathrm{x}}\right) \mathrm{Q}(0, \mathrm{~s}) / \mid \lambda \sqrt{\frac{\mathrm{s}}{\mathrm{a}} \mid} \\
\mathrm{Q}(\mathrm{x}, \mathrm{s})=-\lambda \sqrt{\frac{\mathrm{s}}{\mathrm{a}}} \operatorname{sh}\left(\sqrt{\frac{\mathrm{s}}{\mathrm{a}} \mathrm{x}}\right) \mathrm{T}(0, \mathrm{~s})+\operatorname{ch}\left(\sqrt{\frac{\mathrm{s}}{\mathrm{a}} \mathrm{x}}\right) \mathrm{Q}(0, \mathrm{~s})
\end{array}\right.
$$


Where $T(x, s)$ is the Laplace transform from temperature to time at the position $x, Q(x, s)$ is the Laplace transform from heat flux to time at the $\mathrm{x}$ section, $\mathrm{s}$ is the Laplace transform of $\tau$ ( $\tau$ representing time), $a$ is thermal diffusivity, $\mathrm{m}^{2} / \mathrm{s}, \lambda$ is thermal conductivity, $\mathrm{W} /(\mathrm{m} \cdot \mathrm{K}), \mathrm{x}[\mathrm{m}]$ is coordinates on the calculated surface, $1[\mathrm{~m}]$ is the thickness of wall.

From equation (4), (5), the temperature responds and heat flux responds in any position can be obtained by Laplace transform method once boundary condition $\mathrm{t}(0, \tau)$ and $\mathrm{q}(0, \tau)$ are known. And equation (5) can be solved by Laplace transform of $\mathrm{T}(\mathrm{x}, \mathrm{s})$ and $\mathrm{Q}(\mathrm{x}, \mathrm{s})$ which is shown in equation (6).

When $\mathrm{x}=1$, then:

$$
\left|\begin{array}{l}
\mathrm{T}(1, \mathrm{~s}) \\
\mathrm{Q}(1, \mathrm{~s})
\end{array}\right|=\left|\begin{array}{cc}
\mathrm{A}(\mathrm{s}) & -\mathrm{B}(\mathrm{s}) \\
-\mathrm{C}(\mathrm{s}) & \mathrm{D}(\mathrm{s})
\end{array}\right| \begin{gathered}
\mathrm{T}(0, \mathrm{~s}) \\
\mathrm{Q}(0, \mathrm{~s})
\end{gathered} \mid
$$

Where:

$$
\begin{aligned}
& \mathrm{A}(\mathrm{s})=\operatorname{ch}(\sqrt{\mathrm{s} / \mathrm{a} \cdot 1}) ; \quad \mathrm{C}(\mathrm{s})=\lambda \sqrt{\mathrm{s} / \mathrm{a}} \cdot \operatorname{sh}(\sqrt{\mathrm{s} / \mathrm{a} \cdot 1}) ; \\
& \mathrm{B}(\mathrm{s})=\operatorname{sh}(\sqrt{\mathrm{s} / \mathrm{a}} \cdot 1) /(\lambda \sqrt{\mathrm{s} / \mathrm{a}}) ; \quad \mathrm{D}(\mathrm{s})=\operatorname{ch}(\sqrt{\mathrm{s} / \mathrm{a}} \cdot 1)
\end{aligned}
$$

$$
\text { When }[G]=\left|\begin{array}{cc}
A(s) & -B(s) \\
-C(s) & D(s)
\end{array}\right|,[G] \text { is transfer matrix of wall system representing thermal }
$$

characteristics of wall system, and is not related to temperature and heat flux on both side of the wall.

\section{Heat Transfer Coefficient}

In solving the heat transfer coefficient, $\mathrm{B}(\mathrm{s})=0$ in the transfer matrix, and $\alpha_{\mathrm{i}} \geq 100$ in transcendental equation. Then heat transfer equation is shown in equation (7):

$$
\begin{array}{ll}
\mathrm{y}_{0}=\mathrm{K}+\sum_{\mathrm{i}=1}^{\infty} \frac{\mathrm{B}_{\mathrm{i}}}{\Delta \tau}\left(1-\mathrm{e}^{-\alpha_{\mathrm{i}} \Delta \tau}\right) & \mathrm{n}=0 \\
\mathrm{y}_{\mathrm{n}}=-\sum_{\mathrm{i}=1}^{\infty} \frac{\mathrm{B}_{\mathrm{i}}}{\Delta \tau}\left(1-\mathrm{e}^{-\alpha_{\mathrm{i}} \Delta \tau}\right)^{2} \mathrm{e}^{-(\mathrm{n}-1) \alpha_{\mathrm{i}} \Delta \tau} & \mathrm{n} \geq 1
\end{array}
$$

Where $\Delta \tau$ is the discrete time interval, $\Delta \tau=1 \mathrm{~h}, \mathrm{Bi}$ is the coefficient, be equal to $-1 /\left[\alpha_{\mathrm{i}}^{2} \mathrm{~B}^{\prime}\left(-\alpha_{\mathrm{i}}\right)\right\rfloor$, $\alpha_{\mathrm{i}}$ is the I-th root, $\mathrm{n}$ is the number of reaction coefficient, $\mathrm{n}=40, \mathrm{~K}$ is the heat transfer coefficient of wall, $\mathrm{W} /(\mathrm{m} 2 \cdot \mathrm{K}), \Delta \tau$ is the discrete time interval, $\Delta \tau=1 \mathrm{~h}, \mathrm{Bi}$ is the coefficient, be equal to $-1 /\left[\alpha_{\mathrm{i}}^{2} \mathrm{~B}^{\prime}\left(-\alpha_{\mathrm{i}}\right)\right], \alpha_{\mathrm{i}}$ is the I-th root, $\mathrm{n}$ is the number of reaction coefficient, $\mathrm{n}=40, \mathrm{~K}$ is the heat transfer coefficient of wall, $\mathrm{W} /(\mathrm{m} 2 \cdot \mathrm{K})$.

\section{Case Research}

For one type of wall, the wall materials are shown in Table2:

Table 2. Wall materals

\begin{tabular}{|c|c|c|}
\hline Wall type & $\begin{array}{c}\text { Thermal Diffusivity } \\
{\left[\mathrm{W} / \mathrm{m}^{2} \cdot{ }^{\circ} \mathrm{C}\right]}\end{array}$ & $\begin{array}{c}\text { Heat transfer } \\
\text { coefficient }\left[\mathrm{kg} / \mathrm{m}^{3}\right]\end{array}$ \\
\hline 1. brick setting $(240 \mathrm{~mm})$ & 0.00184 & 0.81 \\
\hline 2. Lime plaster $(20 \mathrm{~mm})$ & 0.00179 & 0.7 \\
\hline
\end{tabular}




\section{Root of Equation B(s)}

Different height root distribution figures are shown in Fig.1-Fig.4, in which the horizontal coordinates are the roots of $\mathrm{B}(\mathrm{s})$, and the longitudinal coordinates are the values of $\mathrm{B}(\mathrm{s})$.

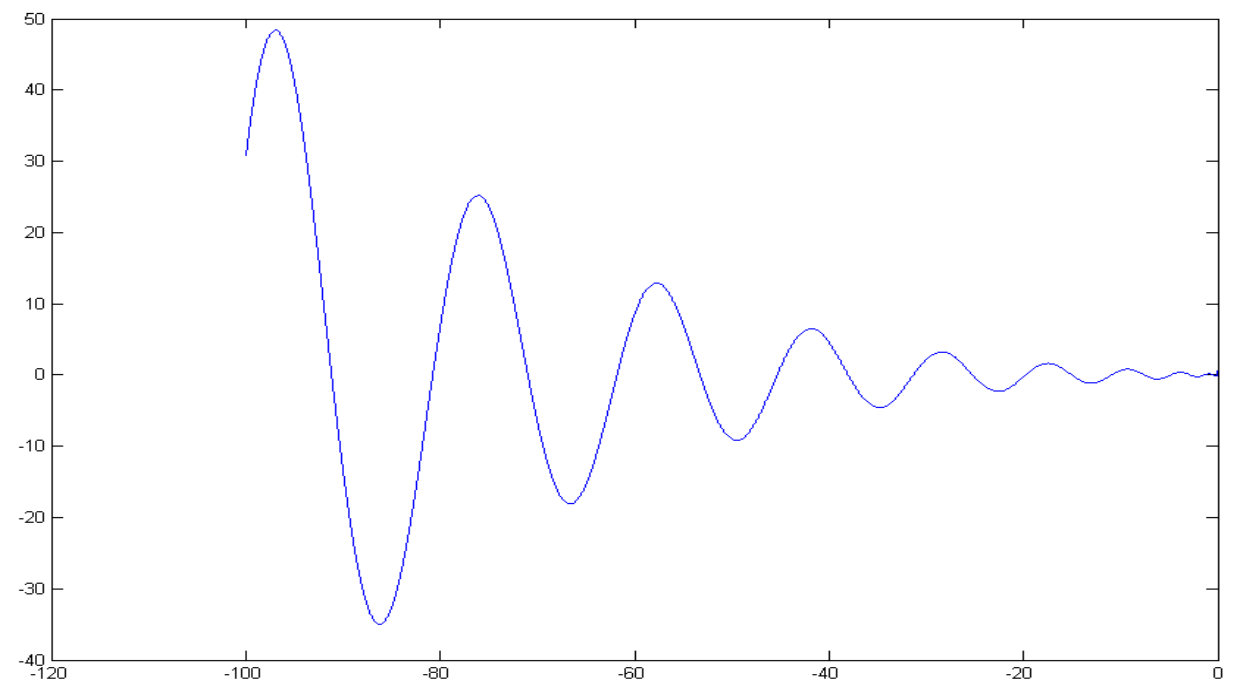

Fig.1 Roots of $B(s)$ in $10 m$ height

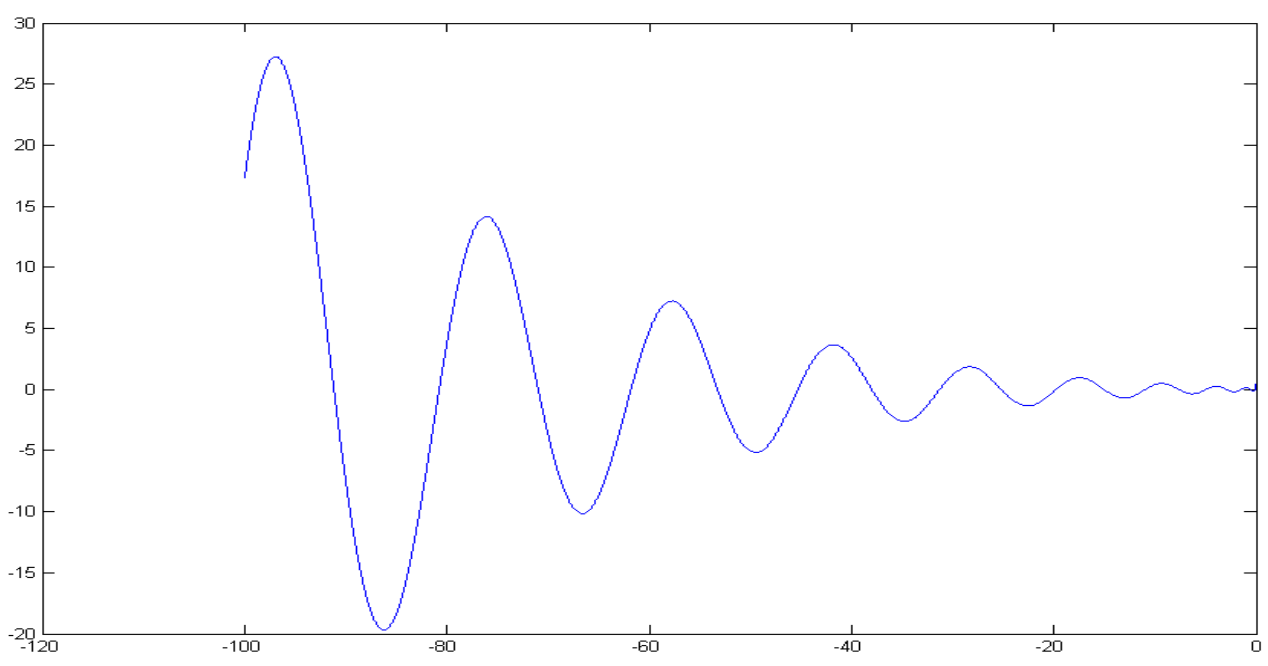

Fig. 2 Roots of $B(s)$ in $100 m$ height

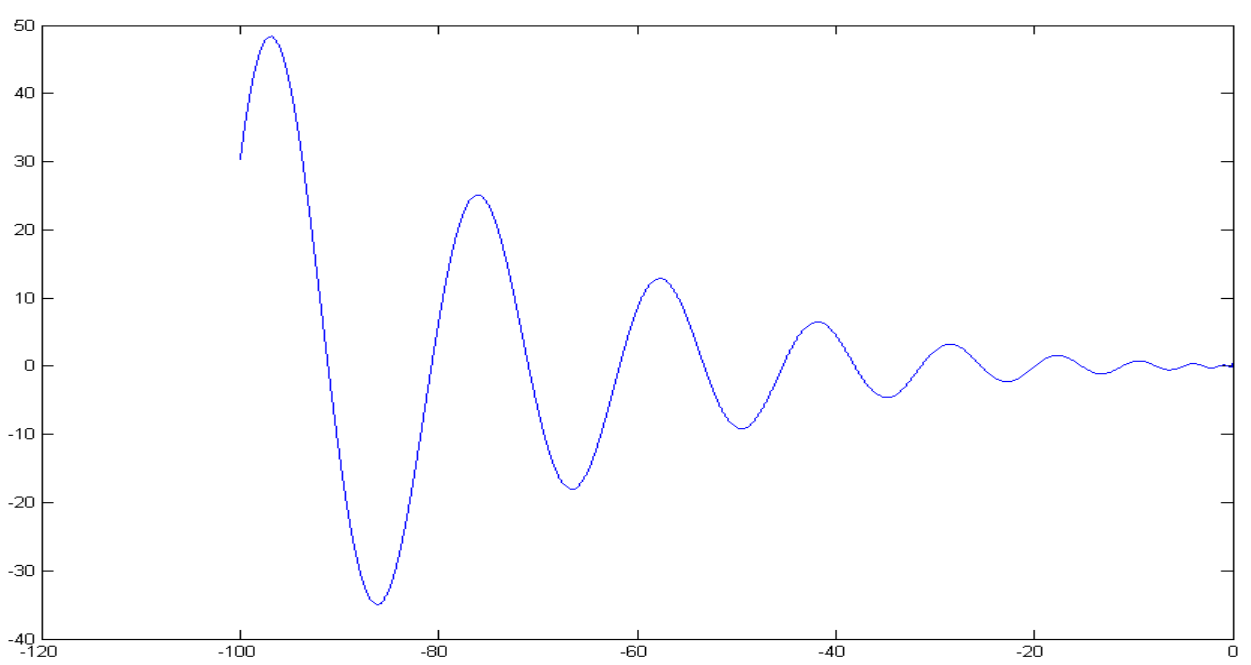

Fig. 3 Roots of $B(s)$ in $200 m$ height 


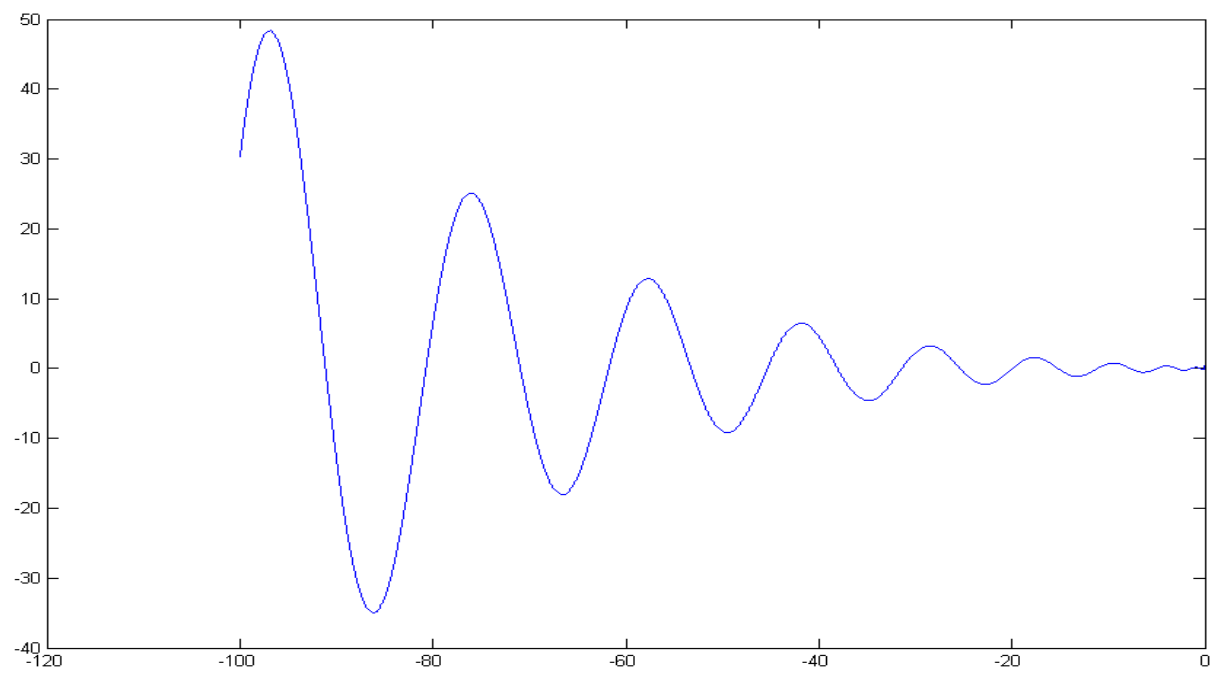

Fig.4 Roots of $B(s)$ in 300m height

Represent the above figures by data in Table3:

Table3. The roots data of $B(s)$

\begin{tabular}{|c|c|c|c|c|c|c|c|}
\hline $\begin{array}{c}\text { Height } \\
10 \mathrm{~m}\end{array}$ & Roots & $\begin{array}{c}\text { Height } \\
100 \mathrm{~m}\end{array}$ & Roots & $\begin{array}{c}\text { Height } \\
200 \mathrm{~m}\end{array}$ & Roots & $\begin{array}{c}\text { Height } \\
300 \mathrm{~m}\end{array}$ & Roots \\
\hline 1 & -0.129 & 1 & -0.141 & 1 & -0.136 & 1 & -0.137 \\
\hline 2 & -0.592 & 2 & -0.646 & 2 & -0.599 & 2 & -0.598 \\
\hline 3 & -1.482 & 3 & -1.58 & 3 & -1.515 & 3 & -1.513 \\
\hline 4 & -2.892 & 4 & -3.021 & 4 & -2.993 & 4 & -2.992 \\
\hline 5 & -4.941 & 5 & -5.041 & 5 & -5.086 & 5 & -5.084 \\
\hline 6 & -7.641 & 6 & -7.717 & 6 & -7.827 & 6 & -7.824 \\
\hline 7 & -11.03 & 7 & -11.06 & 7 & -11.23 & 7 & -11.23 \\
\hline 8 & -15.1 & 8 & -15.1 & 8 & -15.29 & 8 & -15.3 \\
\hline 9 & -19.85 & 9 & -19.85 & 9 & -20.02 & 9 & -20.02 \\
\hline 10 & -25.27 & 10 & -25.27 & 10 & -25.4 & 10 & -25.4 \\
\hline 11 & -31.34 & 11 & -31.34 & 11 & -31.42 & 11 & -31.42 \\
\hline 12 & -38.04 & 12 & -38.04 & 12 & -38.8 & 12 & -38.8 \\
\hline 13 & -45.36 & 13 & -45.36 & 13 & -45.36 & 13 & -45.36 \\
\hline 14 & -53.3 & 14 & -53.3 & 14 & -53.27 & 14 & -53.27 \\
\hline 15 & -61.84 & 15 & -61.84 & 15 & -61.8 & 15 & -61.8 \\
\hline 16 & -71 & 16 & -71 & 16 & -70.95 & 16 & -70.95 \\
\hline 17 & -80.78 & 17 & -80.78 & 17 & -80.74 & 17 & -80.74 \\
\hline 18 & -91.18 & 18 & -91.18 & 18 & -91.14 & 18 & -91.14 \\
\hline
\end{tabular}




\section{Response Coefficient}

According to equation (7), the reaction coefficient is calculated as Table4:

Table4. Reaction coefficient values in different heights

\begin{tabular}{|c|c|c|c|c|c|c|c|}
\hline \multicolumn{2}{|c|}{ Height $10 \mathrm{~m}$} & \multicolumn{2}{|c|}{ Height $100 \mathrm{~m}$} & \multicolumn{2}{c|}{ Height $200 \mathrm{~m}$} & \multicolumn{2}{c|}{ Height 300m } \\
\hline $\mathrm{j}$ & $\mathrm{Y}$ & $\mathrm{j}$ & $\mathrm{Y}$ & $\mathrm{j}$ & $\mathrm{Y}$ & $\mathrm{j}$ & $\mathrm{Y}$ \\
\hline 1 & 0.0017 & 1 & 0.0067 & 1 & 0.0066 & 1 & 0.0083 \\
\hline 2 & 0.0425 & 2 & 0.0556 & 2 & 0.0521 & 2 & 0.0536 \\
\hline 3 & 0.1048 & 3 & 0.129 & 3 & 0.1208 & 3 & 0.1224 \\
\hline 4 & 0.1481 & 4 & 0.1754 & 4 & 0.1662 & 4 & 0.1679 \\
\hline 5 & 0.1661 & 5 & 0.1905 & 5 & 0.1834 & 5 & 0.185 \\
\hline 6 & 0.167 & 6 & 0.1866 & 6 & 0.1822 & 6 & 0.1836 \\
\hline 7 & 0.1587 & 7 & 0.1733 & 7 & 0.1715 & 7 & 0.1727 \\
\hline 8 & 0.1462 & 8 & 0.1565 & 8 & 0.1565 & 8 & 0.1575 \\
\hline 9 & 0.132 & 9 & 0.139 & 9 & 0.1404 & 9 & 0.1412 \\
\hline 10 & 0.1182 & 10 & 0.1224 & 10 & 0.1247 & 10 & 0.1252 \\
\hline 11 & 0.105 & 11 & 0.1072 & 11 & 0.1099 & 11 & 0.1103 \\
\hline 12 & 0.093 & 12 & 0.0935 & 12 & 0.0966 & 12 & 0.0969 \\
\hline 13 & 0.0821 & 13 & 0.0815 & 13 & 0.0847 & 13 & 0.0848 \\
\hline 14 & 0.0723 & 14 & 0.0709 & 14 & 0.0741 & 14 & 0.0741 \\
\hline
\end{tabular}

\section{Conclusions}

Reaction coefficient appears to increasing trend which is accord to the actual situation in above analysis. It can be deduced that heating load and cooling load will increase with the increase of the building height. In the calculations of cooling load and heating load, the reaction coefficient should be adjusted with the building height regardless of simulation method or tabular computation. The adjusted route will help to improve the accuracy of design, especially be beneficial to optimize consultation.

\section{References}

[1] Tiantian Yang, Daxue Lu, Ruojing Wang, Zhanshan Wang. The Influence on Low-E Glass of Wind Speed Changing with Building's Height, 2007, 26(2):79

[2] S.E.G.JAYAMAHA, N.E.WIJEYSUNDERA, S.K.CHOU. Measurement of the Heat Transfer Coefficient for Wall, Building and Environment, 1996,31(5),399

[3] Qisen Yan, Qingzhu Zhao. Building Heat Process. Beijing :China Architecture \& Building Press, 1986. 